\title{
A HISTORICIDADE DOS DIREITOS HUMANOS E OS PENSAMENTOS DE BOBBIO E ARENDT NA CONSTRUÇÃO DO DIREITO AO TRABALHO E AO LAZER
}

\section{THE HISTORICITY OF HUMAN RIGHTS AND THE THOUGHTS OF BOBBIO AND ARENDT IN THE CONSTRUCTION OF THE RIGHT TO WORK AND LEISURE}

Daniela Menin'

\begin{abstract}
RESUMO: A partir das premissas apontadas por Norberto Bobbio em sua obra "A Era dos Direitos" e por Hannah Arendt, em sua obra "A condiçăo Humana",verifica-se a historicidade dos Direitos Humanos e sua influência no ordenamento jurídico brasileiro, particularmente na Constituiçăo Federal de 1988 e na construçâo teórica, positivaçăo e efetividade do direito do trabalho e do direito ao lazer do trabalhador. Neste sentido, o enfoque principal está na historicidade dos Direitos Humanos defendida por Bobbio e na importância do direito ao trabalho e ao lazer destacado por Hannah Arendt.". Também recebe destaque neste trabalho as Cartas Encíclicas Pacem in Terris e Rerum Novarum, que figuram como elemento importante na historicidade dos Direitos Humanos, inclusive na construçăo do Direito do trabalho.
\end{abstract}

Palavras-chave: direitos humanos; direitos fundamentais; direito do trabalho; direito ao lazer.

ABSTRACT: Based on the premises pointed out by Norberto Bobbio in his work "The Age of Rights" and by Hannah Arendt, in his work "The Human Condition", the historicity of Human Rights and its influence in the Brazilian legal system, particularly in the Constitution Federal law of 1988 and in the theoretical construction, positivation and effectiveness of labor law and the right to leisure of the worker. In this sense, the focus is on the historicity of Human Rights advocated by Bobbio and on the importance of the right to work and leisure highlighted by Hannah Arendt. "Also worthy of mention in this work are the Encyclical Letters Pacem in Terris and Rerum Novarum, which figure as an important element in the historicity of Human Rights, including the construction of Labor Law

1 Possui graduaçáo em Direito pelo Centro Universitário da Grande Dourados (1998), Bacharel em Teologia pelo Seminário Presbiteriano Renovado Brasil Central (2009) de Anápolis/GO, pós-graduaçáo em Direito Público pela Universidade Anhanguera-Uniderp (2012). É advogada nas áreas cível, trabalhista e previdenciária. Mestra em Fronteiras e Direitos Humanos pela Universidade Federal da Grande Dourados. Pesquisa Direito ao Lazer e outros aspectos do Direito do Trabalho. danameninadv@gmail.com. 
Keywords: human rights; fundamental rights; Labor law; Right to leisure.

\section{INTRODUÇÃO}

Compreender a construçâo conceitual dos Direitos Humanos e sua positivaçâo sob a perspectiva histórica é de fundamental importância para poder enfrentar a discussão sobre o alcance universal dos direitos humanos. Ainda que, segundo a Declaraçấo Universal dos Direitos Humanos da Organizaçâo das Naçôes unidas de 1948, todos nasçam iguais e portadores de direitos, a história da humanidade tem demonstrado que cada direito e cada garantia assegurados ao indivíduo săo frutos de lutas históricas. Ou foram respostas às barbáries ocorridas mundialmente, ou resultado de acontecimentos históricos e lutas sociais, todos com o objetivo comum de emancipar o indivíduo, desenvolvê-lo, promover a sua dignidade como pessoa humana e consequentemente, criar uma sociedade mais justa e pacífica. A compreensâo dessa trajetória histórica é fundamental para analisar a efetividade desses direitos, uma vez que, embora positivados, muitos padecem de evoluçăo e efetivaçăo.

Também é possível observar o caráter de universalidade dos direitos humanos, na medida em que a Declaraçâo de 1948 influenciou nâo somente a elaboraçâo de outras declaraçōes protetivas, mas também várias Constituiçōes.

O estudo tem caráter analítico e busca extrair dos autores citados o fundamento para a análise dos reflexos da Teoria Geral dos Direitos Humanos na construçâo do ordenamento jurídico brasileiro, mais especificamente no que se refere ao direito ao trabalho e ao lazer. Aborda os aspectos gerais dos direitos humanos, com ênfase em sua historicidade, explanando de que forma a Declaraçăo Universal dos Direitos Humanos de 1948 refletiu no mundo e na criaçâo de dispositivos que promovessem e preservassem tais direitos. 0 artigo também explana a respeito de outros aspectos importantes dos Direitos do Homem, como indivisibilidade e heterogenia, abordando também a necessidade que ainda há de efetivaçăo de alguns direitos.

Os reflexos da Declaraçâo Universal dos Direitos Humanos também na construçâo da Constituiçâo Federal de 1988, que por sua vez, positivou vários direitos sociais fundamentais, inclusive o direito ao trabalho e ao lazer.

\section{ELEMENTOS HISTÓRICOS DOS DIREITOS HUMANOS}

Para falar de Direitos Humanos é preciso entendê-los como fruto de construçôes jurídicas ao longo da história, voltados para o aprimoramento da sociedade e para uma convivência pacífica entre os indivíduos e também entre os povos, visando a promoçâo da dignidade humana para todos os indivíduos. A este respeito, Piovesan (2015, p.188) acrescenta que "enquanto reivindicaçôes morais, os direitos humanos săo fruto de um espaço simbólico de luta e açăo social, na busca por dignidade humana, o que compóe um construído axiológico emancipatório".

É a partir dessa premissa que Norberto Bobbio (2004) entende ser possível verificar que os mais diversos contextos históricos, associados às ideologias diferentes e a clamores e necessidades específicas de vários grupos de indivíduos, compuseram o 
cenário para o surgimento de um dos mais importantes marcos internacionais de positivaçâo dos Direitos Humanos: A Declaraçấo dos Direitos Humanos da Organizaçáo das Naçôes Unidas, em 1948. ${ }^{2}$

Neste sentido, Bobbio (2004) ressalta em sua obra, "A era dos Direitos", que năo existe um único fundamento que justifica a construçăo da Declaraçâo de 1948, até mesmo pelo fato de que houve todo um processo dinâmico e dialético, de forma que a elaboraçâo formal do documento, ponto de partida de para a proteçăo desse direitos, foi uma resposta, uma reaçấo global às atrocidades e barbáreis praticadas principalmente no segundo pós-guerra.

Ou seja, a Declaraçâo dos Direitos Humanos foi construída como resposta aos anseios da humanidade para uma convivência coletiva harmônica e livre, através de conquistas que se solidificaram ao longo dos anos.

Do ponto de vista teórico, sempre defendi - e continuo a defender, fortalecido por novos argumentos - que os direitos do homem, por mais fundamentais que sejam, săo direitos históricos, ou seja, nascidos em certas circunstâncias, caracterizadas por lutas em defesa de novas liberdade contra velhos poderes, e nascidos de modo gradual, năo todos de uma vez e nem de uma vez por todas. (2004,p.25)

Tal ensinamento de Bobbio é confirmado pela própria história. Observa-se que a Declaraçâo de 1948 também antecedeu outros importantes documentos que contribuíram para consagrar direitos e garantias fundamentais, servindo de inspiraçăo para Constituiçōes de várias naçôes e também para que, no âmbito internacional, houvesse a expansâo da positivaçấo de vários direitos. Neste sentido, destaca-se a Convençăo para a Prevençăo e a Repressăo do Crime de Genocídio, também de 1948, as Convençôes de Genebra sobre a Proteçâo das Vítimas de Conflitos Bélicos, firmada em 1949, a Convençăo Europeia dos Direitos Humanos, data de 1950, os Pactos Internacionais de Direitos Humanos, de 1966, a Convençăo Americana de Direitos Humanos, de 1969, e o Estatuto do Tribunal Penal Internacional, de 1998.

Assim, Bobbio ensina que a partir de movimentos e acontecimentos históricos, passou-se à reflexáo e posterior conclusâo da necessidade de firmar pactos e tratados que pudessem garantir o mínimo de dignidade a qualquer indivíduo. E, de fato, muitos outros documentos surgiram no sentido de confirmar o que já havia sido declarado e também para ampliar as conquistas que, embora indispensáveis a qualquer indivíduo, ainda eram bastante recentes e precárias, no que diz respeito a sua efetividade.

É importante ressaltar que vários acontecimentos históricos contribuíram para a construçâo da positivaçâo dos Direitos Humanos, entre eles, a Revoluçâo Francesa. Os idealistas franceses tinham na frase "liberdade, igualdade e fraternidade" o lema do movimento. Norberto Bobbio (2004) teve a perspicácia de destacar as geraçóes dos direitos humanos baseados no lema da Revoluçấo Francesa, afirmando que o

2 A Europa foi cenário para que no século XIX, surgissem as primeiras constituiçôes, com destaque para a siciliana de 1812, a espanhola de Cádiz, de 1812, a francesa de 1814 e posteriormente de 1848, a portuguesa de 1822 e a belga de 7 de fevereiro de 1831. Tais documentos foram também motivadores para a positivaçăo e consagraçăo normativa dos direitos humanos. E ainda neste mesmo aspecto de importância, é possível citar a Convençâo de Genebra que versava sobre a Escravatura, datada de 1926 e também a Relativa ao Tratamento de Prisioneiros de Guerra, de 1929. COMPARATO, Fábio Konder. A afirmaçăo histórica dos direitos humanos. 4. ed. Săo Paulo: Saraiva, 2005, pp. 196-221. 
"desenvolvimento dos direitos do homem passou por três fases" que săo as três primeiras geraçōes/dimensôes clássicas.

A primeira geraçăo săo direitos de natureza política e civil e foram reconhecidos para a tutela das liberdades públicas. Refletem a liberdade do indivíduo com relaçáo ao Estado, onde o mesmo deve abster-se de executar determinados atos para que os direitos do indivíduo sejam gerados, preservados, exercidos, etc. Refletem a passagem do absolutismo para o Estado de Direito, com ênfase na busca da valorizaçăo do indivíduo e no estabelecimento de barreiras do poder do Estado. (LAFER,1988). Săo os direitos individuais e indispensáveis à pessoa humana, entre eles, o direito à locomoçâo, inviolabilidade de domicílio, correspondência, etc.

Os direitos de segunda geraçăo fazem parte do grupo mais significativo para este estudo, pois nele reside a raiz do direito trabalhista e, consequentemente, do direito ao lazer. Este grupo reflete uma importante conquista para a classe trabalhadora, um segundo momento do capitalismo, com o aprofundamento das relaçóes entre o capital e o trabalho. Este relacionamento fomentou o aparecimento dos direitos chamados sociais, incluindo o seguro social, subsistência, amparo à doença e velhice, etc. O foco era promover a melhoria da qualidade de vida do cidadăo (BOBBIO, 2004). Sáo exemplos desse grupo de direitos as férias remuneradas, o décimo terceiro salário, o salário mínimo, aposentadoria, previdência, etc.

Por fim, destaca-se o grupo de terceira geraçăo, que corresponde aos direitos de fraternidade. O Estado já năo protege apenas os interesse individuais e sociais mas também outro tipo de direitos, decorrentes de sociedades de massa, dos processos de urbanizaçâo e industrializaçăo produzidos pelos homens. É como se o Estado estivesse protegendo o homem do próprio homem, por isso também pode ser elencado neste grupo, a proteçăo às relaçôes de consumo.

Assim, Bobbio ressalta que a Declaraçāo dos Direitos Humanos representa que os valores humanos podem ser positivados e fundamentados, refletindo o consenso de que săo válidos para toda a humanidade, contribuindo para formar uma comunidade internacional de pessoas livres e iguais.

\section{OUTROS ASPECTOS DOS DIREITOS HUMANOS, SEGUNDO NORBERTO BOBBIO}

Norberto Bobbio (2004) entende ser possível verificar que os mais diversos contextos históricos, associados às ideologias diferentes e a clamores e necessidades específicas de vários grupos de indivíduos, compuseram o cenário para o surgimento documentos importantes para a compreensăo e desenvolvimento dos Direitos Humanos.

Mas para Norberto Bobbio, conceituar o que sâo os direitos humanos náo se resume a dizer que săo direitos naturais, pertencentes a todo indivíduo. É preciso também esclarecer que é necessário lutar por eles, para que seu reconhecimento e exercício assegurem o aperfeiçoamento da pessoa humana, e dessa forma, o desenvolvimento da civilizaçăo. Importante ressaltar que para Bobbio, os direitos humanos săo históricos, que se desenvolveram ao longo dos anos mas que ainda precisam e tem potencial para que seu alcance e desenvolvimento seja ainda maior. É este também o 
entendimento de importantes estudiosos (ARENDT,2000; LAFER,1988;cPIOVESAN, 2015) que além de defenderem a historicidade dos direitos humanos, também ensinam que seráo construídos e reconstruídos ao longo do tempo, ainda que, como ensina especificamente Bobbio (2004,p.30), nasçam como direitos naturais universais, desenvolvendo-se como direitos positivos particulares e alcancem a plena realizaçấo como direitos positivos universais.

Assim, Bobbio assegura que o valor da pessoa humana é um direito positivo, reconhecido e democratizado, em um primeiro momento, na esfera do ordenamento jurídico interno. Mas que de fato existe a universalizaçăo dos direitos humanos e atribui tal fator à Declaraçâo Universal dos Direitos Humanos de 1948, sendo ela um dos principais documentos que promoveram a interdependência de ordenamentos e a positivaçâo internacional de direitos. Essas características, positivaçâo e universalidade, serăo marcantes para Bobbio defender a desnecessidade de fundamentaçâo dos direitos humanos, que também rejeita de plano a existência de apenas um único e absoluto fundamento que justifique a existência de todos os Direitos Humanos. Caso existisse este único elemento justificador, haveria óbice para que demais direitos pudessem ser reconhecidos e positivados.

Pois bem: dois direitos fundamentais, mas antinômicos, năo podem ter, um e outro, um fundamento absoluto, ou seja, um fundamento que torne um direito e o seu oposto, ambos, inquestionáveis e irresistíveis. Aliás, vale a pena recordar que, historicamente, a ilusấo do fundamento absoluto de alguns direitos estabelecidos foi um obstáculo à introduçăo de novos direitos, total ou parcialmente incompatíveis com aqueles. Basta pensar nos empecilhos colocados ao progresso da legislaçăo social pela teoria jusnaturalista do fundamento absoluto da propriedade: a oposiçấo quase secular contra a introduçáo dos direitos sociais foi feita em nome do fundamento absoluto dos direitos de liberdade. $O$ fundamento absoluto năo é apenas uma ilusăo; em alguns casos, é também um pretexto para de fender posiçōes conservadoras. (2004, p. 15)

Mas também é preciso observar que os direitos humanos săo heterogêneos e ainda assim se completam. Um exemplo é de que há os direitos de liberdades, que săo aqueles garantidos quando o Estado nâo intervém, mas também há os direitos que săo garantidos apenas com a intervençâo do mesmo.

Além disso, os direitos humanos também nâo sâo herméticos, uma vez que podem ser ampliados, justamente por serem variáveis. Para Bobbio, é possível afirmar que, apesar de muitos direitos já estarem positivados, outros tantos virăo, e isso significa que năo existe algum direito que seja inato, mas todos devem ser construídos.

O elenco dos direitos do homem se modificou, e continua a se modificar, com a mudança das condiçōes históricas, ou seja, dos carecimentos e dos interesses, das classes no poder, dos meios disponíveis para a realizaçâo dos mesmos, das transformaçóes técnicas, etc. Direitos que foram declarados absolutos no final do século XVIII, como a propriedade sacre et inviolable, foram submetidos a radicais limitaçóes nas declaraçōes contemporâneas; direitos que as declaraçóes do século XVIII nem sequer mencionavam, como os direitos sociais, sâo agora proclamados com grande ostentaçăo nas recentes declaraçôes. Nâo é difícil prever que, no futuro, poderáo emergir novas pretensóes que no momento nem sequer podemos imaginar, como o direito a náo portar armas contra a própria vontade, ou o direito de respeitar a vida também dos animais e nâo só dos homens. 
Assim, os direitos humanos săo absolutamente indispensáveis para assegurar a todos uma existência digna, livre e igual. O fato é que eles sâo fruto de inúmeros acontecimentos e de discussōes e evoluçōes históricas extremamente importantes para a humanidade. Por conta disso, inspiraram inúmeras constituiçôes federais, inclusive as brasileiras, como será exposto mais à frente.

\section{NECESSIDADE DE EVOLUÇÃO E EFETIVIDADE DOS DIREITOS HUMANOS}

Ainda com relaçấo à natureza dos Direitos Humanos, além de apresentar a convicçâo de que os mesmos sâo construçôes históricas, Bobbio também demonstra que săo mutáveis, dinâmicos e aptos a serem aprimorados e expandidos. Essa historicidade reflete que os direitos humanos năo nasceram de uma única só vez, mas foram forjados por circunstâncias e estăo sujeitos a serem ampliados por outros elementos ao longo dos anos, conforme a necessidade dos povos, conforme já explanado.

Assim, para Bobbio, o que tem aspecto de fundamentalidade numa determinada época histórica e civilizaçăo, pode năo ter o mesmo aspecto em outras épocas ou em outras naçóes (2004). Porém, o que năo se pode admitir é o retrocesso, a retraçáo e a diminuiçāo daquilo que já foi conquistado.

Dessa forma, ainda que o pleno desenvolvimento do homem seja prioridade, é importante ressaltar que até mesmo os direitos fundamentais à promoçăo da dignidade humana, năo sâo ilimitados, uma vez que a Declaraçăo dos Direitos Humanos das Naçôes Unidas, prevê expressamente, em seu artigo 29 a relatividade destes direitos:

Todo o homem tem deveres para com a comunidade, na qual o livre e pleno desenvolvimento de sua personalidade é possível.

No exercício de seus direitos e liberdades, todo o homem estará sujeito apenas às limitaçôes determinadas pela lei, exclusivamente com o fim de assegurar o devido reconhecimento e respeito dos direitos e liberdades de outrem e de satisfazer as justas exigências da moral, da ordem pública e do bem-estar de uma sociedade democrática.

Esses direitos e liberdades náo podem, em hipótese alguma, ser exercidos contrariamente aos objetivos e princípios das Naçôes Unidas. Nenhuma disposiçáo da presente Declaraçăo pode ser interpretada como o reconhecimento a qualquer Estado, grupo ou pessoa, do direito de exercer qualquer atividade ou praticar qualquer ato destinado à destruiçáo de quaisquer direitos e liberdades aqui estabelecidos. (2004,p.13)

Mas Norberto Bobbio também traz à discussăo, que tăo importante quanto a positivaçăo dos direitos humanos, é a efetividade e a evoluçăo dos mesmos. Assim, o autor explana que muitos direitos foram proclamados nas Declaraçóes, garantidos pelo constitucionalismo e, assim, estâo revestidos de solenidade, mas despidos da necessária efetividade para o indivíduo possa usufruí-los em sua essência.

Nada impede que se use o mesmo termo para indicar direitos apenas proclamados numa declaraçăo, ate mesmo solene, e direitos efetivamente protegidos num ordenamento jurídico inspirado nos princípios do constitucionalismo, onde haja juízes imparciais e várias formas de poder executivo das decisōes dos juízes num 
ordenamento jurídico inspirado nos princípios do constitucionalismo, onde haja juízes imparciais e várias formas de poder executivo das decisōes dos juízes. Mas entre uns e outros há uma bela diferença! já a maior parte dos direitos sociais, os chamados direitos de segunda geraçáo, que săo exibidos brilhantemente em todas as declaraçóes nacionais e internacionais, permaneceu no papel. 0 que dizer dos direitos de terceira e de quarta geraçáo? A única coisa que até agora se pode dizer é que săo expressáo de aspiraçóes ideais, às quais o nome de "direitos" serve unicamente para atribuir um título de nobreza. Proclamar o direito dos indivíduos, năo importa em que parte do mundo se encontrem (os direitos do homem săo por si mesmos universais), de viver num mundo nâo poluído năo significa mais do que expressar a aspiraçáo a obter uma futura legislaçáo que imponha limites ao uso de substâncias poluentes. Mas uma coisa é proclamar esse direito,outra é desfrutá-lo efetivamente. A linguagem dos direitos tem indubitavelmente uma grande funçăo prática, que é emprestar uma força particular às reivindicaçôes dos movimentos que demandam para si e para os outros a satisfaçáo de novos carecimentos materiais e morais; mas ela se torna enganadora se obscurecer ou ocultar a diferença entre o direito reivindicado e o direito reconhecido e protegido (2004, p.29).

Para Bobbio, năo basta a mera proclamaçăo dos Diretos dos Homens, é preciso a promoçăo dos mecanismos para que os mesmos năo se limitem ao campo das ideias e tomem força de prática e açâo.

A respeito dos direitos sociais, Bobbio (2004) alerta para a realidade de países em desenvolvimento năo conseguirem desenvolvê-los de modo satisfatório. Mais precisamente a respeito do direitos do trabalho, o autor destacou que năo basta a proclamaçăo, fundamentaçăo ou proteçăo. Este somente poderia encontrar a sua eficácia máxima a partir da evoluçâo da sociedade.

Aliás, a tendência de flexibilizar e até mesmo de extirpar os direitos fundamentais, inclusive os sociais, parece ser uma tendência acentuada dos dias atuais, prestes a corromper de forma incisiva tanto a democracia quanto a paz, elementos definidos por Bobbio como problemas fundamentais, que, quando violados, comprometem a estabilidade social.

A princípio, a enorme importância do tema dos direitos do homem depende do fato de ele estar extremamente ligado aos dois problemas fundamentais do nosso tempo, a democracia e a paz. O reconhecimento e a proteçáo dos direitos do homem săo a base das constituiçóes democráticas, e, ao mesmo tempo, a paz é o pressuposto necessário para a proteçăo efetiva dos direitos do homem em cada Estado e no sistema internacional. Vale sempre o velho ditado - e recentemente tivemos uma nova experiência - que diz inter arma silente leges. Hoje, estamos cada vez mais convencidos de que o ideal da paz perpétua só pode ser perseguido através de uma democratizaçấo progressiva do sistema internacional e que essa democratizaçăo năo pode estar separada da gradual e cada vez mais efetiva proteçáo dos direitos do homem, democracia e paz săo três momentos necessários do mesmo movimento histórico: sem direitos do homem reconhecidos e efetivamente protegidos náo existe democracia, sem democracia năo existem as condiçôes mínimas para a soluçáo pacífica dos conflitos que surgem entre os indivíduos, entre grupos e entre as grandes coletividades tradicionalmente indóceis e tendencialmente autocráticas que săo os Estados, apesar de serem democráticas com os próprios cidadāos. 
Se os Direitos Humanos se prestam a promover a paz e o desenvolvimento dos indivíduos, como de fato se prestam, encontram barreira para seu pleno potencial assecuratório da dignidade humana náo somente na falta de efetivaçăo de muitos deles, mas também no processo contrário, ou seja, na tendência bastante acentuada que há em desconsiderar o caráter de fundamentabilidade dos mesmos e assim, promover a flexibilizaçăo daquilo que, ao menos em tese, nâo deveria ser nem ao menos mitigado.

\section{INFLUÊNCIAS DA DECLARAÇÃO UNIVERSAL DOS DIREITOS HUMANOS DE 1948 NA CONSTITUIÇÃO FEDERAL DE 1988}

A Carta de 1988 é considerada como um marco jurídico de transiçăo democrática e da institucionalizaçăo dos direitos humanos no país (PIOVESAN, 2015), fruto de um extenso processo de democratizaçăo, iniciado após vinte e um anos de ditadura militar que perdurou de 1964 a 1985.

Assim, a Constituiçăo Federal de 1988 institucionalizou um regime politico democrático, e inegavelmente, foi responsável por colocar novamente o Brasil no cenário internacional, ao lado de naçóes que também resguardam e promovem a defesa e garantias fundamentais ao ser humano. Portanto, a Carta de 1988 se relaciona com todo o arcabouço internacional de proteçăo aos direitos humanos, considerando cada um deles como uma unidade indivisível, interdependentes e inter-relacionados.

Nesta sistemática, observa-se que a Constituiçâo Federal adotou uma divisâo onde o termo "direitos fundamentais" é gênero dividido em espécies, quais seja, direitos individuais, coletivos, sociais, nacionais e políticos. Assim, observa-se que as Constituiçôes escritas estăo vinculadas às declaraçôes de diretos fundamentais. Aliás, a própria Declaraçăo dos Direitos Humanos de 1948 cita como um dos motivos determinantes da Carta, o comprometimento dos povos em zelar pelos direitos, garantias e liberdades fundamentais.

Ao analisar a Constituiçăo Federal Brasileira de 1988 é possível observar que todas essas dimensōes, geraçóes ou fases dos direitos descritos por Bobbio, delinearam os direitos fundamentais dos cidadăos, estando dispostos como direitos sociais e individuais, no preâmbulo. Já os direitos e deveres individuais e coletivos, constam do Capítulo I do Título II, direitos humanos, dispostos no art. $4^{\circ}$, II, direitos e liberdades fundamentais, art. $5^{\circ}$, XLI, direitos e liberdades constitucionais, no art. $5^{\circ}$, LXXI, direitos civis, art. $12, \S 4^{\circ}$, direitos fundamentais da pessoa humana, art.17, caput, direitos da pessoa humana, art. 34, VII, b, direitos e garantias individuais, art. $60, \S$ $4^{\circ}$, IV e direito público subjetivo, no art. $208, \S 1^{\circ}$.

Há de se considerar que os direitos sociais săo os mais relevantes para o presente estudo, mais especificamente os direitos ao trabalho e ao lazer. Neste sentido, é salutar observar que a Constituiçấo Federal de 1988 enquadra o trabalho como um dos princípios gerais da atividade econômica, declarando como tais a valorizaçâo do trabalho humano e da livre iniciativa (art.170) e busca do pleno emprego (artigo 170,VIII). Entre os direitos e garantias fundamentais inclui o direito ao livre exercício do trabalho, oficio e profissăo, atendidas as qualificaçôes profissionais que a lei estabelecer. 
Portanto, ainda que carente de efetivaçâo, os direitos fundamentais do indivíduo encontram na atual Constituiçấo Federal, aquilo que se apresenta como o padrâo mínimo existencial para uma existência digna (BARUFFI,2010). Assim, nota-se que há no art. 60, $\S 4^{\circ}$. Inc. IV, CF, elementos que nâo podem ser objeto de deliberaçấo. Ou seja, năo será jamais permitido que as propostas de emenda constitucional, causem a aboliçấo das garantias individuais de uma forma geral, náo somente dos direitos sociais, mas de todos aqueles considerados fundamentais. Existe, portanto, uma barreira, um escudo que se constitui uma medida de proteçăo em torno dos direitos fundamentais, já que os mesmos săo elementos que văo garantir a continuidade da Constituiçăo.

\section{AS CONTRIBUIÇÕES DAS ENCÍCLICAS "PACEM IN TERRIS" E "RERUM NOVARUM" PARA OS DIREITOS AO TRABALHO E AO LAZER}

Após as duas grandes guerras, o mundo passou a voltar a atençăo para a construçâo de ordenamentos que pudessem promover a paz e a dignidade da pessoas humana. Dessa forma, a Declaraçăo Universal dos Direitos Humanos de 1948 inspirou a escrita dos mais diversos tipos de documentos que visavam a ampliaçăo e a positivaçáo dos mesmo.

Mas é de se observar que inclusive instituiçóes religiosas, como a Igreja Católica Apostólica Romana, engajaram-se na luta e manifestaram-se a respeito dos direitos humanos, através de alguns documentos escritos pelos papas. Um deles, ainda que escrito anteriormente à Declaraçâo de 1948, é apto a atestar a historicidade dos direitos humanos, uma vez que revela a preocupaçăo da Igreja Católica com o tratamento que estava sendo dispensado aos trabalhadores da época. Datada de 1891 e escrita por pelo Papa Leâo XIII, o documento abordou a "questăo social", delineando inclusive quais eram as obrigaçōes tanto de patrōes quanto de empregados.

Nota-se a ênfase na necessidade e no respeito no trato com a classe trabalhadora, com a severa condenaçăo à opressấo enfatizando o respeito e a dignidade dos trabalhadores. Dessa forma, a Encíclica "pontifica uma fase de transiçấo para ajustiça social, traçando regras para a intervençăo estatal na relaçâo entre trabalhador e patrấo."(MARTINS, 2011). Assim, quando fala da obrigaçăo dos operários e dos patrôes, o documento reforça que todo trabalho deve ser digno, isento de humilhaçôes e discriminaçōes.

Quanto aos ricos e aos patrôes, năo devem tratar o operário como escravo, mas respeitar nele a dignidade do homem, realçada ainda pela do Cristăo. 0 trabalho do corpo, pelo testemunho comum da razăo e da filosofia cristă, longe de ser um objeto de vergonha, honra o homem, porque lhe fornece um nobre meio de sustentar a sua vida. $\mathrm{O}$ que é vergonhoso e desumano é usar dos homens como de vis instrumentos de lucro, e náo os estimar senáo na proporçáo do vigor dos seus braços. $\mathrm{O}$ cristianismo, além disso, prescreve que se tenham em consideraçăo os interesses espirituais do operário e o bem da sua alma. Aos patróes compete velar para que a isto seja dada plena satisfaçăo, para que o operário náo seja entregue à seduçấo e às solicitaçôes corruptoras, que nada venha enfraquecer o espírito de família nem os hábitos de economia. Proíbe também aos patrôes que imponham aos seus subordinados um trabalho superior às suas forças ou em desarmonia com a sua idade ou o seu sexo. 
Portanto, é possível observar a preocupaçăo com a dignidade humana do trabalhador estampada nas linhas da Rerum Novarum, inclusive com ênfase no cuidado com o trata espiritual e físico.

Já a Carta Encíclica Pacem in Terris, do Papa Joăo XXIII, de abril de 1963, fala a respeito de várias diretrizes e preceitos dirigidos nâo somente aos padres, bispos, arcebispos, ao membros do clérigo de uma forma em geral, aos católicos, e também a todos "homens de boa vontade", revelando seu caráter ecumênico e abrangente. Suas recomendaçōes eram no sentido de promover uma sociedade mais justa, com valores sólidos que promovessem e conservassem a dignidade da pessoas humana. Assim, a oitava e última Encíclica do Papa Joâo XXIII, é considerada a Encíclica da Paz e da dignidade humana e ressalta a importância da colaboraçăo mundial para promoçáo da paz e de uma sociedade equilibrada e justa.

O documento, obviamente tem a mençâo de conceitos religiosos, mas traz em seu corpo também, a demonstraçăo de que a Igreja Católica estava com sua atençâo voltada para os valores sociais que deveriam ser exercidos num mundo que ainda buscava se recuperar das barbáries, depois das duas grandes guerras. 0 texto demonstra que Joâo XXIII recomendava o reconhecimento da dignidade de todos os seres humanos. Assim, referiu-se à Declaraçâo Universal dos Direitos Humanos de 1948, e que se tornou uma referência e uma inspiraçăo para os povos empenhados na afirmaçăo dos princípios e valores democráticos, buscando uma integraçâo dinâmica entre os direitos e deveres individuais, os direitos e deveres políticos e os direitos e deveres sociais. Mais um elemento que corrobora para o conceito de universalidade tanto da Declaraçăo, quanto dos próprios Direitos Humanos.

Segmentos da sociedade da época abrem o seu olhar e voltam a sua atençấo para a ascensâo econômico-social das classes trabalhadoras, o ingresso da mulher na vida pública, o fim do colonialismo e das discriminaçôes sociais, a participaçâo das pessoas na vida política e social do país, apontando, ainda que năo explicitamente, para o modelo da democracia participativa e a necessidade e a urgência da paz no interior das comunidades nacionais e da comunidade internacional. É o que se observa na Encíclica Pacem in Terris, especificamente no que diz respeito ao trabalho e a importância do mesmo para a formaçāo do indivíduo.

\section{$[\ldots]$}

18. No que diz respeito às atividades econômicas, é claro que, por exigência natural, cabe à pessoa năo só a liberdade de iniciativa, senăo também o direito ao trabalho.

19. Semelhantes direitos comportam certamente a exigência de poder a pessoa trabalhar em condiçôes tais que náo se lhe minem as forças físicas nem se lese a sua integridade moral, como tampouco se comprometa o săo desenvolvimento do ser humano ainda em formaçăo.

É importante observar que há uma ênfase de que, para que haja a garantia de dignidade ao indivíduo, o mesmo deve ter acesso ao trabalho, de forma que garanta seu sustento, mas também desenvolva seus valores como ser humano. Há também a mençăo de que tal trabalho năo pode ser penoso, nem esgotar as forças físicas, de forma que ofenda a sua honra.

Ou seja, aquilo que nasceu para ser um direito, para garantir qualidade de vida, uma existência digna, deve, necessariamente cumprir a sua funçấo. Neste sentido, 
Hannah Arendt, ${ }^{3}$ em seu livro "A condiçăo Humana", traça reflexôes a respeito do trabalho, uma das atividades mais essenciais para o ser humano, que se presta náo somente a promover o próprio sustento, mas também a definir a identidade do indivíduo, uma vez que reflete a sua própria condiçăo de humanidade.

Dessa forma, estabelece um paralelo entre o que é o trabalho, labor e obra, elementos que ela caracteriza como vita activa, Diante do cenário de desenvolvimento industrial da Europa e a consequente expansăo da classe operária, a autora questiona "o que estamos fazendo?", numa referência à análise necessária ao exercício dos direitos conquistados e da inserçăo do indivíduo na vida política, através da formaçâo da sua identidade social e formaçăo da sua singularidade. Através disso, o homem poderia se revelar ao mundo como homem, mas, do contrário, promovido o isolamento, instaura-se o regime totalitário.

Aliás, os regimes totalitários inspiraram Arendt a questionar a organizaçâo política adotada pela sociedade moderna e sobre quais motivos e elementos sáo produzidos pelo próprio homem, a ponto de submeter toda uma sociedade a tais regimes opressores, e assim, mitigando ou até mesmo eliminando os direitos humanos. Em sua obra, "As origens do totalitarismo", a autora expôe que a solidăo e o desamparo săo as bases para a implantaçăo de tal regime. Assim, tais elementos fazem com que o homem náo se sinta pertencente ao mundo, ainda que seja um homo faber, ou seja, alguém produtivo, mas supérfluo, sem uma vida privada. (ARENDT, 2000)

Tal introduçâo do pensamento de Hannah Arendt é necessária, pois assim será possível compreender os questionamentos feitos em "A condiçâo humana", a respeito daquilo que é produzido/desenvolvido pelo homem através do labor, trabalho e açâo, explicando o que realmente pode e deve ser produtivo e o que nada acrescenta ao homem.

Os dois conceitos mais importantes para este estudo sâo os apresentados por Arendt: "labor" e "trabalho". Ao definir labor,Hannah Arendt esclarece que o mesmo sempre está ligado a fadigas, ao esforço e à dor, que geram a deformaçăo do ser humano. O labor está intimamente ligado ao processo biológico do ser humano e assegura a sobrevivência do indivíduo e também de toda espécie. Assim, "a condiçâo humana do labor é a própria vida", segundo Arendt. Cumpre ressaltar que para a filósofa, o labor também está diretamente associado ao consumo, elementos de um só processo.

Por outro lado, o trabalho é tudo aquilo produzido pelo homem; "a condiçâo humana do trabalho é a mundanidade". Produz um pouco mais de significado à vida, em que pese o caráter fútil da mesma, por meio da permanência e durabilidade. Mas tanto o labor quanto o trabalho estăo associados ao fluxo da vida, à "Vida Activa", à

3 Hannah Arendt contribuiu de forma exponencial ao pensamento contemporâneo, nâo somente pelo profundo conhecimento da Filosofia Clássica, mas também pela forma original e única de interpretar a Filosofia Moderna, além de seu sensível e preciso olhar humanista do indivíduo. Seu pensamento traz luz ao estudo dos Direitos Humanos, definindo o ser humano năo somente como detentor de direitos, mas sim como alguém que, aos exercê-los, pode sempre se aprimorar como indivíduo em todas as esferas da sua identidade. $O$ pensamento de Arendt traduz que, para que haja o bem comum, é preciso náo somente respeitar mas desenvolver os direitos fundamentais dos indivíduos, de que forma que os mesmos possam se expandir em todas as suas potencialidades, e, consequentemente, formar uma sociedade mais equilibrada e justa. 
existência e perpetuaçăo da espécie, uma vez que preparam o mundo para o recebimento das novas geraçōes.

A partir das reflexôes de Hannah Arendt, é possível compreender que muitos indivíduos estáo de fato laborando, inseridos na sociedade de consumo, mas nem todos alcançaram o patamar de usufruir o prazer e a alegria de trabalhar, já que, segundo a autora, o trabalho está erroneamente associado à falta de lazer, sendo que o primeiro excluiria o segundo.

Diz-se frequentemente que vivemos numa sociedade de consumidores; e uma vez que, como vimos, o labor e o consumo săo apenas dois estágios de um só processo, importo ao homem pelas necessidades da vida, isto é o mesmo que dizer que vivemos numa sociedade de operários ("labores"), ou seja, de homem que "laboram".

(...) Essa sociedade năo surgiu em decorrência da emancipaçăo das classes trabalhadoras, mas resultou da emancipaçăo da própria atividade do labor, séculos antes da emancipaçăo politica dos trabalhadores. $O$ importante năo é que, pela primeira vez na história, os operários tenham sido admitidos com iguais direitos na esfera pública, e sim que quase conseguimos nivelar todas as atividades humanas, reduzindo-as ao denominado comum de assegurar as coisas necessárias à vida e de produzi-las em abundância. O que quer que façamos, devemos fazê-lo a fim de "ganhar o próprio sustento".

(...)A mesma tendência de reduzir todas as atividades sérias à condiçăo de prover o próprio sustento é evidente em todas as atuais teorias de trabalho, que quase unanimemente definem o trabalho como o oposto ao lazer. Em consequência, todas as atividades sérias, independentemente dos frutos que produzam, sáo chamadas de "trabalho", enquanto toda atividade que năo seja necessária, nem para a vida do indivíduo nem para o processo vital da sociedade, é classificada como lazer.

Dessa forma, percebe-se que desde o início, o conceito de que quem trabalha nâo tem lazer, é bastante inerente à definiçăo do trabalho e do labor. A inserçăo do indivíduo na sociedade de consumo (ou também denominada "promoçâo do sustento") era, e ainda é, a prioridade daquele que labora. O resto é supérfluo, é luxo. Aliás, Arendt também acrescenta que o labor năo evoluiu a ponto de extirpar a ideia de que "toda atividade năo relacionada com o labor torna-se 'hobby'". Ou seja, o indivíduo deveria eleger entre aquilo que lhe seria aprazível e o próprio sustento. Até hoje esta necessidade de escolha se repete. Mas, inserido numa sociedade em que consumir é sobreviver e para sobreviver é preciso trabalhar, o indivíduo elege o trabalho e sacrifica o lazer.

É importante ressaltar que Hannah Arendt fala a respeito de Direitos Humanos com a propriedade de quem nâo somente assistiu a violaçấo cruel dos direitos de toda uma naçấo, mas de quem sofreu as dores de um dos períodos mais reprováveis da raça humana, no que diz respeito a violaçăo de tais direitos. Talvez daí justifique sua identidade com o humanismo e com a capacidade de olhar o indivíduo com uma visăo tâo profunda a ponto de questionar se os direitos aos quais ele está recebendo acesso, de fato estâo promovendo transformaçăo positiva e aprimoramento da sua essência. E assim ela expóe que o lazer năo exclui o trabalho, uma vez que se complementam e ambos săo inerentes à condiçăo humana.

Ou seja, ainda que năo trate abertamente a respeito dos Direitos Humanos, nem mesmo use tal terminologia, o pensamento de Arendt a respeito da condiçáo humana 
muito contribui para a análise da importância prática dos mesmos, uma vez que traz reflexóes sobre de que forma os direitos já conquistados podem ou náo promover ou preservar a dignidade humana do indivíduo. Cabe, neste contexto, pensar a respeito da forma como os mesmos sâo exercidos.

Assim, através deste conceito sobre trabalho e lazer, é possível adentrar nas definiçóes de importância para o indivíduo, tanto do direito do trabalho, quanto do direito ao lazer, ainda sob a égide de que ambos săo definidos como direitos fundamentais, ainda que o segundo padeça de efetivaçăo.

\section{O DIREITO SOCIAL AO TRABALHO}

Tăo difícil quanto proteger, preservar e fomentar mecanismos para a sua evoluçăo, é dar visibilidade aos Direitos Humanos. No que diz respeito aos grupos de direitos sociais, o direito do trabalho nem sempre é considerado como um direito humano.

Acompanhando os ventos do constitucionalismo social do início do século XX, o direito do trabalho, como princípio fundamental, é inserido na Constituiçâo Federal de 1937. A partir deste importante marco, várias leis foram promulgadas a fim de assegurar direitos aos trabalhadores. Assim, em 1943, houve a Consolidaçâo das Leis do Trabalho, pelo Decreto-Lei 5.452 de $1^{\circ}$ de maio de 1943, a CLT. Em seguida, várias inovaçōes ocorreram no sentido de fortalecer ainda mais as relaçóes trabalhistas, inclusive com alguns constando na Constituiçăo Federal de 1946, mas foi com a promulgaçâo da Carta Magna em 1988, com o apogeu do processo de democratizaçấo do país, que houve a ampliaçăo considerável dos direitos sociais, particularmente, dos direitos trabalhistas.

Nota-se, portanto, que o direito ao trabalho e seus desdobramentos săo assegurados na Declaraçâo dos Direitos Humanos de 1948 e, mais tarde, vieram a refletir diretamente na estruturaçăo da Consolidaçăo das Leis do Trabalho brasileira (BARROS,2008).

No âmbito trabalhista brasileiro, a previsăo constitucional é o sinal da evoluçăo dos direitos humanos de um modo geral e do reconhecimento da importância deste direito para a vida do ser humano e para o próprio trabalhador. Assim, há no art. 60, § $4^{\circ}$. Inc. IV, CF, elementos que năo podem ser objeto de deliberaçăo. Ou seja, náo deveria ser jamais permitido que as propostas de emenda constitucional, causassem a aboliçấo das garantias individuais.

Nota-se, portanto, que o direito ao trabalho e seus desdobramentos e também o direito ao lazer, sâo assegurados na Declaraçâo dos Direitos Humanos e, mais, vieram a refletir diretamente na estruturaçăo da Consolidaçấo das Leis do Trabalho brasileira (BARROS, 2008).

Assim, a Declaraçăo dos Direitos Humanos em seus artigos 23 e 24, faz a previsăo expressa de que o trabalho e aspectos inerentes, devem ser objeto de atençăo e proteçấo, bem como o direito ao lazer, uma vez que preconiza que é direito de toda pessoa o repouso, o lazer, a limitaçăo razoável da jornada de trabalho e inclusive de férias periódicas remuneradas. Tais preceitos estăo dispostos năo somente nos artigos da CLT mas em leis complementares, no intuito de assegurar a dignidade humana do trabalhador. 


\section{O DIREITO SOCIAL AO LAZER DO TRABALHADOR}

Como dito, tăo essencial à promoçăo da dignidade do ser humano quanto qualquer outro direito fundamental, é o direito do trabalho. E para o trabalhador, é indispensável o lazer. Porém, tal direito, ainda que seja essencial, năo é efetivado no ordenamento jurídico brasileiro, ainda que esteja expressamente declarado na Constituiçâo Federal.

Aliás, nem mesmo há um consenso na definiçăo do que seria o direito ao lazer do trabalhador. Ao tentar definir o tema, Bolzan de Morais(1995) estabelece que o mesmo está intimamente ligado à qualidade de vida do individuo e embora năo defina quais sâo os parâmetros adotados para tal conceito, assegura que văo muito além das pretensóes de consumo, daquilo que o homem pode adquirir com o seu trabalho e do estilo de vida que passa a ter como fruto do seu labor. Assim, o arcabouço teórico que define "qualidade de vida e lazer", carrega em seu bojo também as opçôes que o indivíduo tem no momento em que năo estiver trabalhando(CALVET,2006;LEITE,1995).

Mas o lazer pode ser um conjunto de ocupaçóes às quais o indivíduo consegue entregar-se de livre vontade, seja para repousar, seja para divertir-se, recrear-se e entreter-se ou, ainda, para desenvolver sua informaçăo ou formaçáo desinteressada, sua participaçăo social voluntária ou sua livre capacidade criadora após livrar-se ou desembaraçar-se das obrigaçôes profissionais, familiares e sociais (DUMAZEDIER, 2004).

As discussōes a respeito do caráter jurídico do direito ao lazer ainda săo esparsas e precárias, se considerado que o direito ao lazer possui caráter de fundamentabilidade tal como os direitos à saúde, educaçăo e moradia. Por isso, é preciso construir um entendimento a partir de conceituaçóes que revelem a importância tanto do direito ao trabalho como dos direitos sociais fundamentais propriamente ditos.

Para construir esta conceituaçăo jurídica, também săo salutares as reflexóes de Magnani (1994), a respeito da origem do lazer na história. O sociólogo apresenta a Revoluçáo Industrial como o que parece ser o embriăo tanto do direito do trabalho quanto do direito ao lazer. Era a passagem do seu modo de vida tradicional, rural e de autossubsistência para a relaçâo de emprego que se formava aos poucos. Inserido neste contexto, o limite da exaustăo física era o único limite conhecido pelo homem trabalhador.

O nascente capitalismo, porém, inaugura uma nova ordem socioeconômica onde a produçăo já năo era determinada pelas necessidades de consumo do grupo doméstico, mas tinha como eixo o mercado, que aliás fornecia um dos fatores envolvidos no processo produtivo: a força de trabalho. O problema da conservaçáo desta última dizia respeito unicamente a seu vendedor que, de posse da remuneraçăo, devia arcar com os custos - alimentaçăo, alojamento, saúde, descanso.

Neste mesmo sentido, Lafargue (2000) alerta que o lazer do trabalhador, somente é possível a partir da limitaçăo labor. E para que isso aconteça, cabe primeiramente ao próprio trabalhador ter e exercer a consciência de que deve lutar para buscar assegurar tempo para si mesmo e para o desenvolvimento de sua individualidade, afinal, tantos outros aspectos de sua vida necessitam de atençăo, năo somente o 
trabalho. Caso náo seja possível, entăo haverá a eterna servidáo ao trabalho, que nâo mais se apresentará como forma de promoçăo da sobrevivência, mas sim como um instrumento de tortura do terrível algoz, o capitalismo.

Se, extirpando do peito o vício que a domina e que avilta sua natureza, a classe operária se levantasse em sua força terrível, náo para exigir os Direitos do Homem, que náo passam dos direitos da exploraçáo capitalista; năo para reivindicar o Direito ao Trabalho, que năo passa do direito à miséria, mas para forjar uma lei de bronze que proíba o trabalho além de três horas diárias, a terra, a velha Terra, tremendo de alegria, sentiria brotar dentro de si um novo universo... Mas como exigir de um proletário corrompido pela moral capitalista uma decisáo tăo viril? Como Cristo, dolente personificaçáo da escravidâo antiga, os homens, mulheres e crianças do proletariado sobem penosamente, há um século, o duro calvário da dor; há um século, o trabalho forçado quebra seus ossos, mata suas carnes, esmaga seus nervos; há um século, a fome retorce suas entranhas e alucina suas mentes!... Preguiça, tenha piedade de nossa longa miséria! Preguiça, măe das artes e das virtudes nobres, seja o bálsamo das angústias humanas!

Assim, o capitalismo, a necessidade de estar inserido no mundo globalizado que produz e consome desenfreadamente, nâo raramente condiciona o homem a priorizar tăo somente o seu meio de sobrevivência, o trabalho

Portanto, o trabalho, o exercício de uma funçâo, profissăo e/ou ofício era (e ainda é) algo indispensável náo somente para mover uma sociedade com suas necessidades e ofertas e assim fazer girar a grande roda de uma estrutura econômica-social, mas também, sob a ótica do indivíduo em si, trazer dignidade ao ser humano, uma vez que torna possível alcançar a paz de espírito, através da promoçăo do seu próprio sustento e o sustento da sua família e dependentes (OLIVEIRA,2010). Por isso está enquadrado no grupo dos direitos fundamentais, grupo este, fruto da evoluçăo social ao longo dos anos em todo o mundo.

Portanto, é preciso ressaltar a sua fundamentabilidade, destacando sempre o desenvolvimento existencial do ser humano, em tudo aquilo que ele é capaz de ser e fazer. E como resume Calvet (2006)quando define juridicamente o direito ao lazer "como o direito fundamental do homem de se desenvolver como ser humano dotado de razâo e desejo, na busca de sua elevaçăo física, psíquica, social e espiritual, estimulando e aprimorando seus talentos e capacidades no interesse que bem lhe aprouver".

Ademais, se o direito ao lazer está incluído no rol dos direitos fundamentais, é pelo fato de ter sido autenticado pelo Estado para propiciar uma vida mais digna ao indivíduo. Porém, năo requer apenas a intervençăo do Poder Público para que possa ir ao seu máximo efeito, mas também exige o respeito nas relaçóes particulares, especificamente, entre patróes e empregados, ainda que seja uma norma de aplicaçâo imediata.

Porém, apesar de estar previsto na Constituiçâo Federal de 1988 e de ser a mesma uma norma de aplicaçâo imediata, o direito ao lazer năo foi sistematizado no ordenamento jurídico brasileiro. Além disso, nâo existe na Constituiçăo Federal e nem na lei infraconstitucional, dispositivo que defina o que é o lazer do trabalhador, nem mesmo na Consolidaçăo das Leis Trabalhistas ou até mesmo na "Reforma Trabalhista" que entre em vigor em novembro de 2017, possui em seu bojo qualquer artigo que traga a definiçâo jurídica do que é o que é lazer e como pode (e se pode) o trabalhador ter acesso a ele. 
O que se percebe é que, com o excesso de labor, o indivíduo passa a ter cada vez menos tempo e vontade de pensar em si mesmo e desenvolver outros aspectos inerente a sua personalidade e identidade. Muitas vezes o obreiro se dá conta de que teve sua saúde e vida social atingidos e prejudicados com o excesso de labor e que năo possui nem tempo livre nem mesmo acesso a nenhum tipo de lazer.

Muitos trabalhadores em todo o pais tem ingressado com reclamatórias trabalhistas, pleiteando dano moral pela supressăo ao lazer, geralmente acompanhado por pedidos de pagamento de horas extras. Assim, tem cabido aos tribunais trabalhistas verificar a violaçâo desse direito, e ponderar se a compensaçăo financeira é eficaz para mitigar os efeitos da mesma.

\section{CONCLUSÕES}

Quase setenta anos depois da sua proclamaçâo, a Declaraçâo Universal dos Direitos Humanos de 1948 continua sendo um dos mais importantes documentos na positivaçăo de tais direitos, responsável, inclusive, por significativas contribuiçōes na construçâo de ordenamentos jurídicos e de elementos importantes da democracia em diversas naçóes. Acima de tudo, foi um importante marco na regulamentaçăo de princípios amplos e universais nas relaçôes sociais. Assim, foi a partir desse processo de positivaçăo, que os direitos humanos passaram do status de orientaçóes éticas ou programas de açâo e alcançaram o patamar de obrigaçôes jurídicas que vinculam as relaçôes internas e externas dos Estados.

Este cenário demonstra que os direitos do homem sâo de fato construçōes histórias, mas săo também produto da dialética entre a conceituaçăo moral e ética e também do esforço jurídico-político, responsável por sua efetivaçâo. Dessa forma, a Declaraçâo dos Direitos Humanos de 1948 influenciou a elaboraçăo das Constituiçóes de muitos países, inclusive da brasileira, de 1988. No âmbito trabalhista brasileiro, a previsăo constitucional é o sinal inequívoco da evoluçáo dos direitos humanos de um modo geral e do reconhecimento da importância deste direito para a vida do ser humano e para o próprio trabalhador. Na Carta Magna, os direitos humanos foram consagrados, recebendo a denominaçáo de direitos fundamentais, revestidos da blindagem da inalterabilidade. Ou seja, năo poderia, jamais serem eliminados nem ao menos diminuídos.

Assim, é possível concluir que a historicidade dos Direitos Humanos apontada por Bobbio explica a evoluçâo de muitos direitos fundamentais ao longo dos anos. Este aspecto do direitos humanos traduz a própria jornada dos direitos trabalhistas, que surgiram, primeiramente na Constituiçấo de 1937, para somente serem consolidados em 1943, que apesar de năo ser um código propriamente dito, reuniu as principais leis trabalhistas. Aliás, tais leis foram recepcionadas pela Constituiçâo de 1988, sendo que muitos direitos trabalhistas foram reconhecidos como direitos fundamentais.

Porém, trajetória ainda singela é a do direito ao lazer, pois, ainda que positivado na Constituiçăo Federal, náo encontra respaldo no ordenamento jurídico brasileiro, de modo que seja plenamente efetivado. E por náo possuir a garantia da efetividade, é passível de violaçaáo. Aliás, nem mesmo existe uma definiçăo do que é o lazer ou de que forma o trabalhador poderia ter acesso a ele. 
Mas, na contra máo dessa recomendaçăo de limitaçăo razoável de jornada, o que comumente ocorre na prática, é a sua supressăo através de jornadas elastecidas e sistemáticas empresariais que sacrificam năo somente o tempo vago do trabalhador, mas também as suas forças físicas e a sua vitalidade. Assim, apesar de ser um direito social, sua visibilidade é tăo precária quanto sua efetividade e certamente sua supressâo é uma violaçâo aos direitos humanos uma vez que promove a coisificaçâo do ser humano, condicionado a apenas trabalhar para ter, sem se preocupar com outro elementos importantes do seu ser, como ter tempo para si mesmo.

Neste estudo, foi possível observar que o pensamento de Hannah Arendt revela a importância para o desenvolvimento do ser humano, tanto do trabalho quanto do lazer. A filósofa aponta que năo há necessidade de um direito excluir o outro, sendo que ambos sấo inerente à condiçấo humana e se prestam a evitar que o ser humano seja coisificado. Ou seja, o indivíduo pode perfeitamente ser um trabalhador que desfruta de uma atividade que promove seu sustento, mas que também tem acesso a momentos de lazer. Este aspecto também reforça o ensinamento de Bobbio de que os direitos sâo indivisíveis e cumulativos. Aliás, compete à dignidade humana de todo indivíduo, jamais ter de abrir măo de algum direito para poder gozar de outro.

Dessa forma, tanto o direito ao trabalho quando o direito ao lazer, assim como os outros direitos relacionados na Declaraçăo Universal dos Direitos Humanos, săo indispensáveis para atender às várias necessidades básicas do indivíduo. Com o lazer, săo sanadas necessidades como de libertaçăo, contrapondo-se à angustia e ao peso que sâo experimentados na angústia que acompanham a vida do trabalhador, principalmente em atividades năo escolhidas livremente.

Porém, é necessário destacar que, apesar dos Direitos Humanos serem históricos, năo pressupóem uma evoluçấo ao longo do tempo, em algumas de suas vertentes. Ou seja, nem sempre o passar dos anos e a positivaçâo dos mesmos significa que o indivíduo está efetivamente usufruindo das conquistas. Um exemplo é o direito do trabalho. Nesta seara, várias conquistas estăo sendo relativizadas e beirando a flexibilizaçâo, ainda que os mesmos estejam revestido de fundamentalidade.

Da mesma forma, é possível observar que o direito ao lazer, apesar de ser previsto, năo foi efetivado, ou seja, náo evoluiu a tal ponto de ser regulamentado. Aliás, no que concerne ao direito ao lazer, é importante compreendê-lo no contexto dos direitos fundamentais, e neste caso, a origem dos mesmos a partir do desenvolvimento histórico das discussóes sobre direitos naturais dos indivíduos, que culminou em 1948 com Declaraçấo dos Direitos Humanos pela Organizaçăo das Naçôes Unidas, como já exposto.

Assim, o que se observa, é que por padecer da tăo necessária efetividade, resta aos tribunais brasileiros analisar fatos concretos de violaçăo ao referido dispositivo em demandas trabalhistas, para garantir a satisfaçăo e/ou reparaçăo deste importante direito do indivíduo, particularmente, do trabalhador.

Promover e proteger a dignidade humana é um dos principais objetivos das Declaraçăo Universal dos Direitos Humanos de 1948 e de vários tratados internacionais, inclusive aqueles construídos para promover e conservar o trabalho em condiçóes dignas, além de promover o direito ao lazer do trabalhador. Neste ponto, há concordância com um dos princípios basilares do direito do trabalho. $\mathrm{O}$ indivíduo, por 
ser um ser holístico, precisa encontrar e desenvolver a vocaçăo dos seus potenciais e o trabalho oferece possibilidades neste sentido. Assim, além de promover o próprio sustento e também de sua família, o trabalhador adquire identidade social, torna-se pertencente a um grupo, desenvolve suas habilidades, etc.

A história demonstra que os direitos humanos, de fato evoluíram. A declaraçăo Universal de 1948 é o padrăo mínimo que deve ser observado nas democracias em todo mundo, e foi capaz de inspirar governos e instituiçôes na consolidaçăo dos direitos dos homens. Porém, as lacunas nos ordenamentos jurídicos internos dos países, inclusive do Brasil, e os exemplos de violaçăo, supressăo e mitigaçâo demonstram que a trajetória dos Direitos Humanos ainda é longa até a sua plena efetivaçâo. 


\section{REFERÊNCIAS BIBLIOGRÁFICAS}

ARENDT, Hannah. A Condiçăo humana. Săo Paulo: Editora Forense Universitária LTDA.1993.

Origens do totalitarismo. Trad. Roberto Raposo. SP: Cia das Letras, 2000.

BALDI, César Augusto. Direitos Humanos na Sociedade Cosmopolita. Rio de Janeiro:

Renovar, 2004.

BARROS, Alice Monteiro de. Curso de Direito do Trabalho. 4. ed. Săo Paulo: L Tr, 2008

BARUFFI, Helder.. Os direitos sociais na Constituiçăo de 1988 e algumas reflexôes em torno de sua concretizaçăo. Anima: Revista Eletrônica do Curso de Direito da Opet, v. III, pp. 80-97, 2010.

BOBBIO, Norberto. A Era dos Direitos. 9 ed. Rio de Janeiro: Elsevier, 2004

BOLZAN DE MORAIS, José Luís. Do direito social aos interesses transindividuais. Tese de Pós Graduaçăo do Curso de Direito da UFSC. Florianópolis, 1995

CALVET, Otávio Amaral. Direito ao lazer nas relaçōes de trabalho. Săo Paulo: LTr, 2006.

CASSAR, Vólia Bomfim. Direito do Trabalho. Săo Paulo: Editora Método, 2013.

CATECISMO DA IGREJA CATÓLICA. Ediçâo típica vaticana. Sâo Paulo: Loyola, 2000, $\S 2246$.

COMPARATO, Fábio Konder. A afirmaçăo histórica dos direitos humanos. 4. ed. Sáo Paulo: Saraiva, 2005.

DUMAZEDIER, Joffre. Lazer e cultura popular. Săo Paulo: Perspectiva, 2004.

JOÅO XXIII, Papa. Encíclica do Papa Joăo XXIII: “Pacem in Terris”- 1963. http://w2.vatican.va/content/john-xxiii/pt/encyclicals/documents/hfj-xxiii_enc_11041963_pacem. html acesso em 02 de dezembro de 2016.

LAFER, Celso. A reconstruçáo dos Direitos Humanos - um diálogo com o pensamento de Hannah Arendt, Săo Paulo, Cia. das Letras, 1988.

LEÂO XIII, Papa, Carta Encíclica Rerum Novarum, http://w2.vatican.va/content/leo -xiii/pt/encyclicals/documents/hf_l-xii__enc_15051891_rerum-novarum.htmlAcesso em 13 de dezembro de 2016.

MAGNANI, José Guilherme C. 0 lazer na cidade. Texto apresentado ao Condephaat. Sáo Paulo, v. 4, 1994.

MARTINS, Sergio Pinto. Direito do Trabalho. 27.ed. Sáo Paulo: Atlas, 2011. p. 8.

OLIVEIRA, Márcio Batista de. 0 direito ao lazer na formaçăo do homem social. Âmbito Jurídico.com.br, XIII, v. 76, 2010.

PIOVESAN, Flávia. Diretos Humanos e o direito constitucional internacional. 15. ed. Săo Paulo: Saraiva, 2015. 